\title{
Radon Exhalation from Industrial Residues as Suitable Additives for Building Materials
}

\author{
H BARROS ${ }^{1}$, G ESPINOSA $^{2}$, W RODRIGUEZ ${ }^{1}$ AND L SAJO-BOHUS ${ }^{1}$ \\ ${ }^{1}$ Universidad Simón Bolívar. Apartado 89000, Caracas 1080 A, Venezuela. \\ ${ }^{2}$ Instituto de Física, Universidad Nacional Autónoma de México, Coyoacán, México \\ *Email: hbarros@usb.ve
}

Published online: August 07, 2017

The Author(s) 2017. This article is published with open access at www.chitkara.edu. in/publications

\begin{abstract}
Radon exhalation from phosphogypsum (PG) and red mud (RM) samples are of environmental concern. The study is oriented to evaluate by different nuclear techniques, industrial materials cumulated in sites at Morón (PG) and Puerto Ordaz (RM) in Venezuela. RM samples and industrial by products are assessed for its potential use as additives in building materials regarding its radiological health risk. Radioactive matter concentration in RM is up to $11.6 \mathrm{kBq} \cdot \mathrm{kg}^{-1}$. Radon concentration range for $\mathrm{RM}$ dry powder is between DL and $2.5 \mathrm{kBq} \cdot \mathrm{m}^{-3}$ and for PG is between 105-340 Bq.m ${ }^{-3}$. Results indicate that industrial by product before it can be used as additive; require remedial actions to lower the environmental impact. Experimental values are compared with locally available cement, bricks and gypsum building materials.
\end{abstract}

Keywords: TENORM, Phosphogypsum, Red Mud, Radon, Building Additives.

\section{INTRODUCTION}

The largest industrial activities in Venezuela, relate to the oil business and heavy industrial mineral processing; these produce toxic and radiotoxic residuals that are of environmental concern. For instance the disposal method, employed by the national aluminium industry during processing large amount of bauxite mineral, is the lagooning. Meaning that industrial residues e.g. red mud (RM) or red slurry, a by-product of the digestion of bauxite ores with caustic soda, is pumped into land based ponds; these are often clay-lined a barrier to contain fluid industrial tail, where it dries under natural weather conditions. This RM wet disposal method, is conveniently employed by several industries worldwide and the Venezuelan CVG Bauxilum industry certainly is

Journal of Nuclear

Physics, Material

Sciences, Radiation and Applications

Vol-5, No-1, August 2017 pp. 113-125 
Barros, $\mathrm{H}$

Espinosa, G

Rodriguez, W

Sajo-Bohus, L not an exception, in spite of been recognized as the most damaging one to the environment since alkaline liquid contaminate local waterways.

During the past decades several studies were carried out to develop an economic way for RM eco-friendly disposal including cost effective remediation processes since the required technology to reduce its environmental impact, was at hand as it is today [1]. We are aware that RM safe disposal or neutralization process or further use could be expensive, as pointed out in reference [2]. However due to RM chemical and mineralogical characteristics other than the large quantity continuously dumped at a rate of around 1-2.5 tons of red mud per ton of produced alumina it could be economically convenient to reprocess RM to recover e.g. gallium having a concentration around 2.0-2.5\% by weight or iron that may reach well above $28 \% \mathrm{w}$. Among proposed solutions to reduce the RM ecological burden, it has been suggested to employ it as additive in clay for brick manufacturing, road construction, building material liner for waste storage among other than metal recovery. The treatment and disposal of this residue is not resolved yet at the Venezuelan alumina plant and on-going studies are currently under way, to find an effective utilization of red mud, including various product developments. In this study some consideration is given since it has been recognize that bauxite ore process inherently favour the technologically enhanced radioactive matter accumulation; therefore RM has to be considered necessarily as a "TENORM waste.. Under this classification, the waste or industrial tail must undergo tests to determine its activity concentration and assess if it met the criteria either for reuse (recycling) or disposal (eco-friendly storage), [2], [3].

In the past, similar environmental concerns have been raised in the case of phosphates rock industrial processing. In that the transfer of radionuclides form radioactive families occurs toward fertilizer end products (worth to observe that about $80 \%$ of the natural Uranium is concentrated in the phosphoric acid with negligible Ra content). On the other hand the PG by product concentrates Radium. Both, ( $\mathrm{U}_{\text {nat }}$ and $\mathrm{Ra}$ ) classifies as diffuse source of TENORM. The phosphoric phosphates deposit site at Riecito in Falcon State, Venezuela reported in Fig1, is considered to be of world-class significance since it was discovered back in 1931.

The exploited site is of an open pit where flotation was the predominant milling method (since 1956). The phosphate rock $\left(27 \%\right.$ of $\left.\mathrm{P}_{2} \mathrm{O}_{5}\right)$ is mined from bed up to $20 \mathrm{~m}$ thick then by road reaches the industrial complex of PEQUIVEN (90 km distant) where phosphoric acid is produced.

Regarding the rock formation, worth to mention that uranium atom replaces calcium up to $0.02 \%$ in the mineral structure of the carbonate Fluor apatite. Therefore, in this case the mining is a NORM industrial process and 
may raise radiological concern. In fact, large volumes TENORM occurrence in commercialized products or wastes may contain radio-toxic elements in different concentrations up to levels that could be a health risk. It is well known that ${ }^{238} \mathrm{U}$ is washed out during the process to be then easily incorporated within the phosphoric acid (near $80 \%$ of the uranium). Radiological impact of products derived from phosphoric acid has its relative importance since uranium concentrations of hundreds of ppm of uranium (not in equilibrium) induce harming long term health effect. In the case of phosphogypsum Radium (mainly its radioisotope ${ }^{226} \mathrm{Ra}$ ) accumulation occurs, causing radiological concern due to radon gas that permeates the environment with energetic alpha particles and gamma rays from decay product of ${ }^{214} \mathrm{~Pb}$ and ${ }^{214} \mathrm{Bi}$ including those related to ${ }^{226} \mathrm{Ra},{ }^{222} \mathrm{Rn},{ }^{218,214,210} \mathrm{Po}$.

The leachability, sorption, and biological incorporation of ${ }^{226} \mathrm{Ra}$, or others radionuclides, are related to their processing history and sitting environment. Therefore it is convenient that waste sites and industrial storage of presumably TENORM rich products should be considered an occupational hazard and radiation protection issue. In the present study we further analyse Venezuelan industrial by products, particularly radon exhalation from red mud (RM) and phosphogypsum (PG) samples by Nuclear Track Methodology (NTM) employing passive detectors (SSNTD) and other nuclear analytical techniques (INAA, ICP-AES, HpGe-spectrometry).

\section{RED MUD AND PHOSPHOGYPSUM TENORM ASPECTS}

The industrial waste production is of high concern due among others to its radioecological impact. Such is the case as mentioned, the red mud large quantity waste released by the alumina industry using bauxite from Los Pijiguaos. The bauxite extracted in the north-west of Bolivar State, is transported through the Orinoco River to Puerto Ordaz City where alumina production is achieved following the Bayer's process (square symbol on Fig. 1); that includes chemical treatment with sodium hydroxide. The byproducts (fine powder fluid waste) are of a red coloured clayish appearance, and contain iron compound in form of oxides, alkali, silicates as well as trace elements e.g. rare earths. It was also observed that some minerals are not affected by the alkaline chemical reactions [4] therefore lower environmental impact is expected. The RM waste site covers several dozens of hectares down to few meters depth and for its radioactive content relate to Thorium family radioisotopes, posing radioecological concern. From the external radiation point of view, several gamma-rays, mainly the high energy one of $2.6 \mathrm{MeV}$ emitted from ${ }^{208} \mathrm{Tl}$ pose health risk. It is convenient to perform
Radon Exhalation from Industrial Residues as Suitable Additives for Building Materials 
Barros, $\mathrm{H}$

Espinosa, $\mathrm{G}$

Rodriguez, W

Sajo-Bohus, L

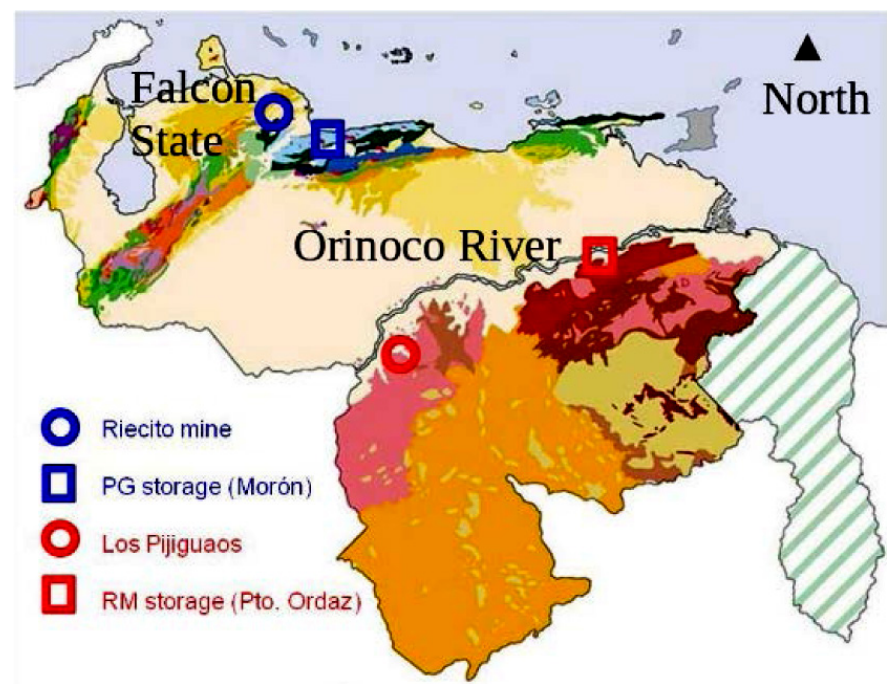

Figure 1: Phosphates rock deposit site (circle) at Riecito (Falcon State north of Venezuela) and location (square) of the industrial complex at Moron (PG storage). Los Pijiguaos (bauxite) mining site (circle) and Puerto Ordaz RM storage site (square) shown in the southern region below the Orinoco River.

general radiometric and radiological survey since also the Uranium family contribute along radon exhalation ${ }^{222} \mathrm{Rn}$ and ${ }^{220} \mathrm{Rn}$ ) to modify environmental radiation level. The outcome could be an indication of the RM aptness as an additive for commercial product.

Another case to which we draw attention is related to the manufacturing of phosphoric acid and it's by product: the hydrated calcium sulphate (gypsum). That contains trace amounts of $\mathrm{RaSO}_{4}$ (mainly the ${ }^{226} \mathrm{Ra}$ ) and if that is coprecipitated with the $\mathrm{CaSO}_{4} \bullet n \mathrm{H}_{2} \mathrm{O}$ yield on average TENORM concentrations from 0.1 to several $\mathrm{kBq} \cdot \mathrm{kg}^{-1}$. The ratio of phosphogypsum (PG) to phosphoric acid production is 5 to 1 ; therefore the low $\mathrm{pH}(1.4-2.5)$ waste has a relatively high concentration of ${ }^{226} \mathrm{Ra},{ }^{238} \mathrm{U}$ and ${ }^{210} \mathrm{~Pb}$. The gypsum in wet environment release radium that behave as $\mathrm{Ca}$ the most relevant in human metabolism and Ba that find few application such as in pharmaceuticals and cosmetics and may enter the biosystems through concentrations in sediments. On the other hand, isotopes of lead-210 and polonium-210 in the PG form are insoluble and enter the life cycle with lower probability, whereas the opposite is true for gypsum that dissolves. Commercially available soil fertilizer (calcium and sulphur) as agricultural product has a TENORM (uranium-238) concentrations in the range of $0.7-2.20 \mathrm{kBq} / \mathrm{kg}$. The product emit harming radioactive radon and 
a limit to radium concentration is set, in particular for ${ }^{226} \mathrm{Ra}$ is $370 \mathrm{~Bq} / \mathrm{kg}$ and for PG pipe scales is $3.7 \times 10^{3} \mathrm{kBq} / \mathrm{kg}$ ), [5]. Therefore, ${ }^{238} \mathrm{U}$ and ${ }^{226} \mathrm{Ra}$ concentrations in any agricultural soil layer may be found several times the expected background value.

\section{RADIATION MEASUREMENTS: SAMPLE CONSIDERATION AND ANALYTICAL TECHNIQUES}

Radon concentrations measured in a purpose made radon chamber by NTM with passive detector such as polyallyldiglycol carbonate (PADC type CR$\left.39^{\mathrm{TM}}\right)$. All the samples were stored in 1 litre glass container and hermetically sealed and stored during 18 days to allow radon equilibration. Dry powder RM samples were spread over the bottom of the container covering similar areas (approx. $20 \times 5 \mathrm{~cm}^{2}$ ) and all the masses were around $235 \mathrm{~g}$. Solid bricks (or blocks) size variation is expected due to the manufacturing process (see https://www .astm.org/Standards/masonry-standards.html). The concrete block and the common clay brick samples were cut from larger bulk matter having cared to maintain the same geometry and volume. Purpose made bricks were manufactured mixing common clay with $25 \%$ and $75 \%$ of red mud respectively. Track detectors were placed inside standardized diffusion chambers (courtesy of NRPB, UK) then introduced with samples in glass containers. Since the phosphogypsum samples did show visible texture heterogeneity (colour, humidity, texture and general appearance) it was convenient to collect for this study, a set of six samples from the surface of the RM stored site. Red mud dried matter was analysed in order to compare radon exhalation value with those measured for the purpose made bricks.

$\mathrm{NRPB} / \mathrm{ISS}$ diffusion chamber with CR-39 ${ }^{\mathrm{TM}}$ often found for radon survey, is a plastic device with a semi-spherical shape of $5.5 \mathrm{~cm}$ diameter with an inner volume of 0.0144 and $2 \mathrm{~cm}$ high (flat bottom) [12], provided with microslits, so that after it is properly closed, allows the diffusion of gases. Radon concentration inside the chamber reaches during measuring time interval, the same level as that prevailing inside the glass bottle ambient air, independent of the radon daughter's concentration. After the mentioned 18 days exposition time, the CR-39 ${ }^{\mathrm{TM}}$ detectors were extracted from the chambers and underwent etching for 6 hours with a $6 \mathrm{~N} \mathrm{NaOH}$ solution in a temperature-stabilized water-bath and mild stirring at $70{ }^{\circ} \mathrm{C}$. The calibration coefficient is 1 track. $\mathrm{cm}^{2}$ per month corresponds to a Radon concentration of $0,434 \mathrm{~Bq} / \mathrm{m}^{3}$. The particular values of the calibration factors depends upon the etching conditions and detector type [6] and influencing parameters were studied by Fiechtner-Scharrer et al (2011)
Radon Exhalation from Industrial Residues as Suitable Additives for Building Materials 
Barros, $\mathrm{H}$

Espinosa, G

Rodriguez, W

Sajo-Bohus, L

[7]. When employing detectors that have different origins, it is convenient to determine their specific calibration factors, [8].

In the case of samples from the industrial waste BAUXILUM pond (Puerto Ordaz, Bolivar state), high energy resolution gamma spectrometry measurements indicate that radioactive concentration is between 2.0 and 3.5 $\mathrm{kBq} \cdot \mathrm{kg}^{-1}[4]$. Nevertheless the international literature [9] reported its utilization as additives in geopolymers [10], [11], clay material, cements, ceramics, fired and no fired breaks [12]. A review on this subject is given by Paramguru et al [13].

In reference to $\mathrm{PG}$ sample preparation we mention that all of them were manually milled, sieved (with mesh of $1 \mathrm{~mm}$ ) and dried.

\section{RESULTS}

TENORM samples, both phosphogypsum and red mud measured values are reported in Table.1.

In Figure 4, we report the gamma ray spectrum for PG as an example to show the radioactive family elements. The concentration of radionuclides

Table 1: Analysed samples and data related to NTM.

\begin{tabular}{llll}
\hline ID & Sample & $\begin{array}{l}\text { Radon conc. } \\
\left(\mathbf{B q} / \mathbf{m}^{3}\right)\end{array}$ & $\sigma\left(\mathbf{B q} / \mathbf{m}^{3}\right)$ \\
\hline PG-1 & Phosphogypsum 1 (powder) & 180 & 130 \\
PG-2 & Phosphogypsum 2 (powder) & 340 & 290 \\
PG-3 & Phosphogypsum 3 (powder) & 105 & 50 \\
PG-4 & Phosphogypsum 4 (powder) & 180 & 55 \\
PG-5 & Phosphogypsum 5 (powder) & 310 & 110 \\
PG-6 & Phosphogypsum 6 (powder) & 160 & 80 \\
CEM & Common Cement (powder) & 210 & 55 \\
GYP & Common Gypsum (powder) & 180 & 55 \\
CON & Common Concrete Block & 160 & 80 \\
RM & Red Mud (powder) & 1560 & 400 \\
B-RM-H & Brick with 75\% of RM (High) & 2550 & 380 \\
B-RM-L & Brick with 25\% of RM (Low) & 1410 & 340 \\
B & Common Clayish Brick & 230 & 160 \\
\hline BKG & Background & 78 & 12
\end{tabular}


Table 2: Radioactivity concentrations of PG and comparison with other PG values.

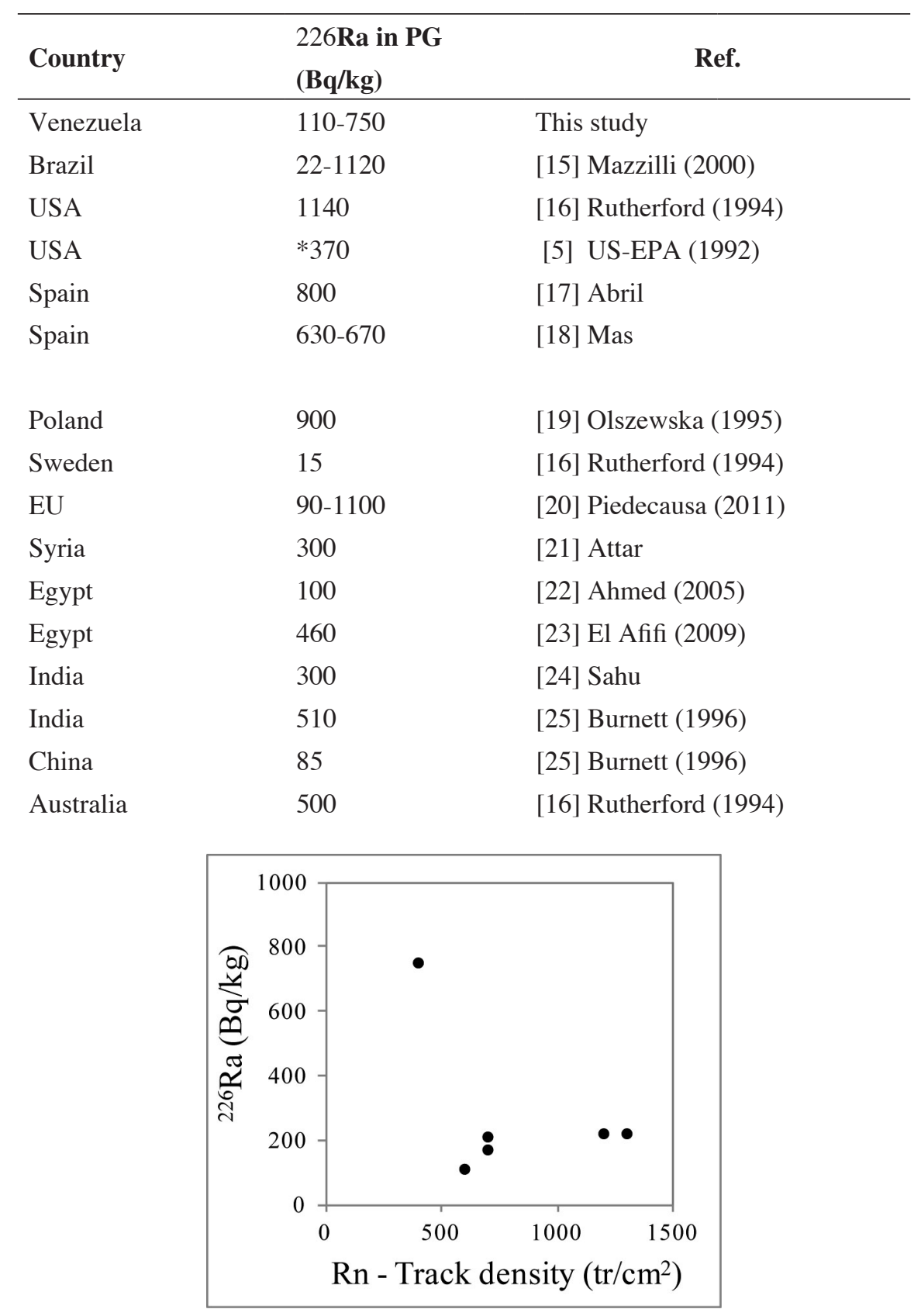

Figure 2: Radium activity concentration vs. Radon track density for PG samples.
Radon Exhalation from Industrial Residues as Suitable Additives for Building Materials 
Barros, $\mathrm{H}$

Espinosa, G

Rodriguez, W

Sajo-Bohus, L

Table 3: Radioactivity concentrations of RM and comparison with other RM world wide.

\begin{tabular}{llll}
\hline Country & $\begin{array}{l}226 \mathbf{R a} \text { in } \mathbf{R M} \\
(\mathbf{B q} / \mathbf{k g})\end{array}$ & $\begin{array}{l}\text { 228Ra in RM } \\
(\mathbf{B q} / \mathbf{k g})\end{array}$ & \multicolumn{1}{c}{ Ref. } \\
\hline Venezuela & $200-330$ & $400-2000$ & This study \\
Jamaica & $370-1150$ & $330-350$ & [26] Pinnock (1991) \\
World & $80-660$ & $70-1800$ & [27] World Aluminum (2015) \\
Australia & 330 & 1130 & [28] Beretka \& Mathew (1985) \\
Australia & 310 & 1150 & [29] Cooper (2005) \\
Australia & $150-600$ & $1000-1900$ & [30] O’Connor (2004) \\
Hungary & $225-570$ & $220-390$ & [31] Somlai (2008) \\
China & $225-480$ & $370-555$ & [32] Gu (2012) \\
Brazil & 140 & 550 & [33] Cuccia (2011) \\
Vietnam & 15 & 30 & [34] Hai (2014) \\
Greece & 380 & 470 & [9] Pontikes (2006) \\
\hline
\end{tabular}

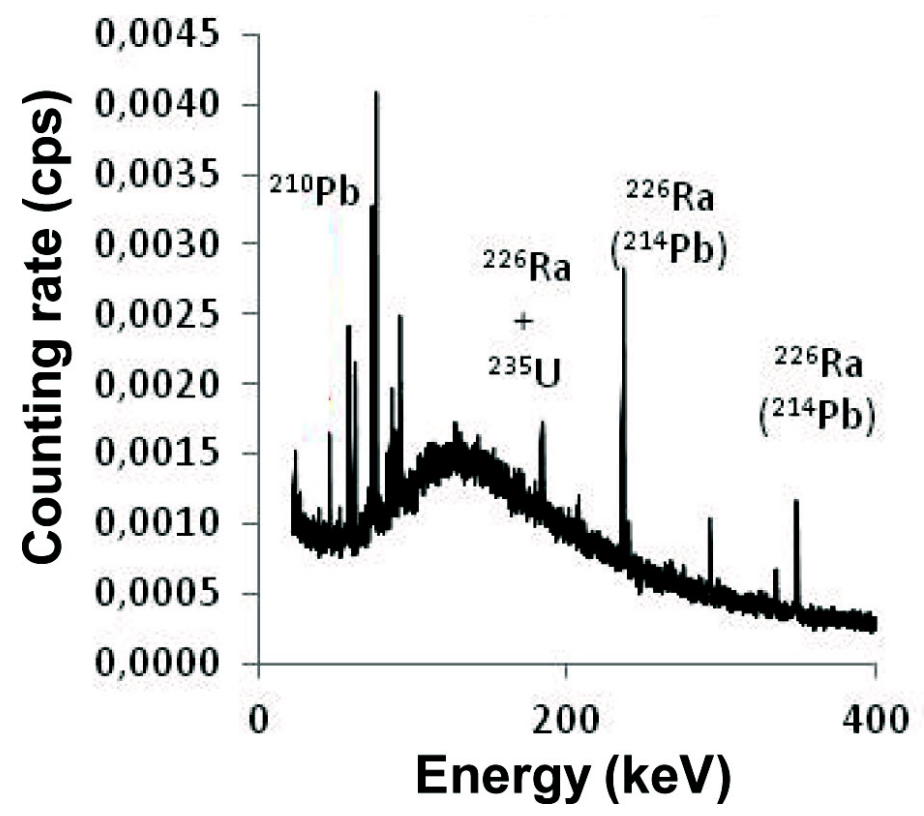

Figure 3: Gamma Spectra of a Phosphogypsum Sample, using a HPGe detector and a standard electronic chain (low energy CANBERRA LEGe) 
of the ${ }^{232} \mathrm{Th}$ series in this kind of samples are quite low, so its radiological implications are negligible, for that reason they were not included in the discussion. In the case of RM samples, the main radioactive contribution comes from ${ }^{232} \mathrm{Th}$ series, as it can be seen in Table 3.

The above mentioned samples were analysed also by a high resolution gamma ray spectrometry. For ${ }^{226} \mathrm{Ra}$ measurements the following gamma lines were considered: 296 and $352 \mathrm{keV}$ form ${ }^{214} \mathrm{~Pb}$ (18.4 and $35.6 \%$ respectively) and $609 \mathrm{keV}$ from ${ }^{214} \mathrm{Bi}$. Also, $238 \mathrm{keV}(43.6 \%)$ of ${ }^{212} \mathrm{~Pb}$ and 338 and 911 $\mathrm{keV}$ lines (11.4 and $25.8 \%$ respectively) of ${ }^{228} \mathrm{Ac}$ were used to evaluate the

${ }^{228} \mathrm{Ra}$ content in the samples. Since density and composition (effective atomic number) vary considerably between samples, a detailed efficiency calibration method was followed as indicated by Díaz and Barros [14].

\section{DISCUSSION AND CONCLUSIONS}

Since all the experiments were performed with a fixed time (18 days) the obtained track densities reflect directly the radon concentrations inside the glass containers and so this measure are indicatives of the Rn exhalation rates from each sample. In order to avoid any bias in the use of the calibration factors, the comparison between samples was done using the track densities. Cement and common gypsum samples produce almost the same amount of Radon while the PG samples produces variable amounts depending on the sample. When powder PG samples are compared with common (commercially available) cement or gypsum (also in powder) it can be seen that values are in the same order of magnitude. Only in the cases of samples PG-2 and PG-5 we observed that produce almost twice as much as Radon than the average of common cement and gypsum. At sight at first, the studied samples do not represent a high radiological risk from the point of view of Radon exhalation. However, there are two other aspects to take into account. First, the Radium content vary in a larger range along the stored volume (and so the do Radon emanation), therefore it is highly advisable to perform a characterization of the artificial deposit with geostatistical criteria since it is the only way to narrow the radioactivity variations. It is especially convenient if material comes from different mines some surficial layer could be correspondingly more radioactive. In a second place, it is necessary to directly measure the radon exhalation from a larger set of matter, since the grain size distribution and porosity influences values of radon exhalation rate. Results from PG samples shows that the Ra activity concentration is quite variable along the sample set, demonstrating the heterogeneity of the material over the surface area, (110 to $750 \mathrm{~Bq} \cdot \mathrm{kg}^{-1}$ of ${ }^{226} \mathrm{Ra}$ pre-equilibrated with its daughters in hermetic containers sealed for 28 days
Radon Exhalation from Industrial Residues as Suitable Additives for Building Materials

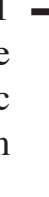


Barros, $\mathrm{H}$

Espinosa, G

Rodriguez, W

Sajo-Bohus, L before measurement). It is important to comment that there is no correlation between the ${ }^{226} \mathrm{Ra}$ activity concentration and the Radon exhalation rate as observable from Figure 2. This observation refroze the above mentioned observation that factors such as grain size distribution, matter porosity and composition of phosphogypsum, drives the radon exhalation rates. However it could not be discarded that a leaching processes intervened on the surface that may have different extents since the samples were consciously selected with different appearances; in fact during sampling some were humid, other very dry, some white, others brownish, among others find along the large storage area (over 12 hectares).

In the case of the RM we mention briefly that the total concentration of the radioactive material contained in red mud is up to $11.640 \mathrm{kBq} \cdot \mathrm{kg}^{\square}$, above the average concentration of building materials, therefore this raw material is suitable as an additive only if processed accordingly. In fact TENORM activity concentration is from 4 to 10 times the limits set for building materials in the European Union. The Venezuelan RM samples having high $\mathrm{pH}$ grade (1112), toxic metals and radioactive elements with concentration hundred times the soil average value, pose a serious and alarming environmental concern. Nevertheless it might be used for land reclamation, for the construction of dams and embankments, or conveniently reprocess again to extract elements such as iron (content 20 to $50 \%$ by weight). The other important point is what we learned from Ajka disaster in Hungary [35], i.e. remedial action should be considered since lowering the $\mathrm{pH}$-value of the $\mathrm{RM}$, has a favourable environmental impact in fact their toxicity is be lower suggesting a rapid vegetation recovery in case of extensive contamination. Most of the red mud is made of an insoluble residue however most damaging process is related to $\mathrm{Al}$ and $\mathrm{Cr}$ being often in a highly mobile water-soluble compound. The most toxic one is $[\mathrm{Al}(\mathrm{OH})(4)](-)$ and $\mathrm{Cr}$ hexavalent form. Reducing red mud alkalinity to $\mathrm{pH} 9$ produce a condition in that $\mathrm{Al}$ solubility is lower and more acceptable from the ecological point of view due to a relatively lower environmental risk level. Remedial actions, at the land based ponds of Pijiguao, is strongly recommended to minimize the risk to contaminate with soluble $\mathrm{Al}$ compounds or $\mathrm{Cr}(\mathrm{VI})$ the Orinoco River water ways including nearby surface waters.

\section{ACKNOWLEDGEMENTS}

Authors acknowledge the phosphogypsum samples supply to PEQUIVEN and to BAUXILUM partial financial support and the red mud matter. The authors with thank to José-Ignacio Golzarri for his technical support. This work was made with a partial economic support of UNAM-DGAPA-PAPIT project IN103316. 


\section{REFERENCES}

[1] H. Sutar, Mishra S. C., Sahoo S. K., Chakraverty A.P. and Maharana H.S. (2014). Progress of Red Mud Utilization: An Overview. American Chemical Science Journal 4(3), 255-279.

[2] C. Klauber, M. Gräfe, G. (2011). Power. Bauxite residue issues: II. Options for residue utilization. Hydrometallurgy 108, 11-32.

[3] B. Omana, A. Gauthier. Reuse Options of Venezuelan Bauxite Residue: Potential Applications in Acid Mine Drainage Remediation. Available in internet Jul 10, 2015. http://conference2015.redmud.org/wp-content/uploads/2015/10/BrendaOMANA-secure.pdf

[4] F. Farina, F. Pino, L. Sneyers, P. Vermaecker, H. Barros, L. Sajo-Bohus, Mackowiak Ma. M, A. Antczak, E. Greaves and D. (2007). Palacios. k0-INAA of Archaeological and Industrial Venezuelan Samples. AIP Conference Proceedings 947. The 7th Latin American Symposium on Nuclear Physics and Applications. 1, 467-468.

[5] US-EPA. (1992). Potential uses of Phosphogypsum and associated risks: Background information document. EPA 402-r92-002. US-EPA, Washington, DC.

[6] C. Orlando, P. Orlando, L. Patrizii, L. Tommasino, S. Tonnarini, R. Trevisi and P. Viola (2002). A Passive Radon Dosemeter Suitable for Workplaces.Radiation Protection Dosimetry Vol. 102, No. 2, 163-168. https://www.researchgate.net/ publication/11055273_A_Passive_Radon_Dosemeter_Suitable_for_Workplaces [accessed May 10, 2017]

[7] Fiechtner-Scharrer A, Mayer S, Boschung M, Whitelaw A. (2011). Influence of variation of etching conditions on the sensitivity of PADC detectors with a new evaluation method. Radiat Prot Dosimetry. 144(1-4), 150-4. doi: 10.1093/rpd/ ncq558.

[8] A. O. Ferreira, Brigitte R. S. Pecequilo and Reginaldo R. Aquino (2013). Efficiency Calibration Factor For Radon Exhalation In Rocks By Using CR-39 SSNTD and The "SEALED-CAN" Technique. International Nuclear Atlantic Conference - INAC 2013, Recife, PE, Brazil, Nov. 24-29.

[9] Y. Pontikes, G.N. Angelopoulos (2013). Resources, Review, Bauxite residue in cement and cementitious applications: Current status and a possible way forward. Conservation and Recycling 73, 53- 63

[10] S.G.Shah, Shemal.V. Dave (2017). Utilization of Red Mud in Geopolymer Concrete-A Review. International Journal of Advance Engineering and Research Development. 4, 730-741

[11] S Singha, S.N. Basavanagowdab, M. U. Aswathc, R. V. Ranganath. Durability of Bricks Coated with Red mud Based Geopolymer Paste. 2016 IOP Conf. Ser.: Mater. Sci. Eng. 149 012070. Available on May 2017: http://iopscience.iop. org/1757-899X/149/1/012070
Radon Exhalation from Industrial

Residues as

Suitable Additives for Building

Materials

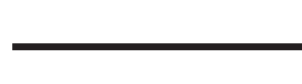


Barros, $\mathrm{H}$

Espinosa, G

Rodriguez, W

Sajo-Bohus, L
[12] S Rai, Dilip H. Lataye, M. J. Chaddha, et al., "An Alternative to Clay in Building Materials: Red Mud Sintering Using Fly Ash via Taguchi's Methodology," Advances in Materials Science and Engineering (2013) 7. doi:10.1155/2013/757923

[13] R. K. Paramguru ,P.C. Rath \& V. N. Misra. (2004) Trends In Red Mud Utilization - A Review. Mineral Processing and Extractive Metallurgy Review. 26, 1-29

[14] R. Diaz and H. Barros (2017). Method for Gamma Spectrometry efficiency calibration for several matrix (in Spanish). Diploma Thesys. Physics Department. Simon Bolivar University. Venezuela.

[15] Mazzilli, B., Palmiro, V., Saueia, C., \& Nisti, M. B. (2000). Radiochemical characterization of Brazilian phosphogypsum. Journal of Environmental Radioactivity, 49, 113-122.

[16] Rutherford, P. M.; Dudas, M. J.; Samek, R. A. (1994) Environmental impacts of phosphogypsum. Science of the Total Environment. 149, 1-2. 1-38.

[17] J.M. Abril., R. García Tenorio., \& G. Manjón. (2009). Extensive radioactive characterization of a phosphogypsum stack in SW Spain: 226Ra, 238U, 210Po concentrations and 222Rn exhalation rate. J. Haz. Mat, 164, 790e797.

[18] Mas, J. L.; San Miguel, E. G.; Bolívar, J. P.; Vaca F.; Pérez-Moreno J. P. (2006). An assay on the effect of preliminary restoration tasks applied to a large TENORM wastes disposal in the south-west of Spain. Sci. Total Environ. 364, pp. 55-66.

[19] Olszewska, W.,M. (1995). Estimates of the occupational radiological hazard in phosphate fertilizers industry in Poland. Radiation Protection Dosimetry, 58, 269-276.

[20] Piedecausa, B., (2011). Radioactividad natural de los materiales de construcción Aplicación al hormigón. Parte I. Radiación externa: Índice de riesgo radioactivo. Revista Técnica CEMENTO HORMIGÓN, N 945, Agosto 2011. ISSN:00088919. pp. 40-65.

[21] Attar, L. A., Al-Oudat, M., Kanakri, S., Budeir, Y., Khalily, H., \& Hamwi, A. A. (2011). Radiological impacts of phosphogypsum. Journal of Environmental Management, 92, 2151-2158.

[22] Ahmed, N.,K. (2005). Measurement of natural radioactivity in building materials in Qena city, Upper Egypt. Journal of Environmental Radioactivity, 83, 91-99.

[23] El Afifi, E. M.; Hilal, M. A.; Attallah, M. F.; El-Reefy, S. A. (2009). Characterization of phosphogypsum wastes associated with phosphoric acid and fertilizers production. J. Environ Radioact. 100, pp. 407-412.

[24] S.K. Sahu, P.Y. Ajmal, R.C. Bhangare, M. Tiwari, G.G. Pandit (2014). Natural radioactivity assessment of a phosphate fertilizer plant area. Journal of Radiation Research and Applied Sciences 7, 123-128. 
[25] Burnett, W. C. Schultz, M. K.; Carter, D. H. (1996). Radionuclide flow during the conversion of phosphogypsum to ammonium sulfate. J. Environ Radioact. 32, 1-2, pp. 33-51.

[26] Pinnock W.R. (1991). Measurements of Radioactivity in Jamaican Building Materials and gamma dose equivalents in a prototype red mud house. Heal. Phys. 61-5, 647-651.

[27] World Aluminum. (2015) Bauxite Residue Management: Best Practice Web site (visited january 2017) http://bauxite.world-aluminium.org/home/

[28] Beretka, J. and Mathew, P. (1985). Natural Radioactivity of Australian Building Materials, Industrial Wastes and By-Products. Health Physics, 48, 87-95.

[29] Cooper. M. B. (2005). Naturally Occurring Radioactive Materials (NORM) in Australian Industries. Review of Current Inventories and Future Generation. EnviroRad Services Pty. Ltd. (ERS-006)

[30] B.H. O'Connor (2004). Public submission prepared for Alcoa World Alumina Australia http://analizebasilicata.altervista.org/blog/wp-content/ uploads/2016/10/NORM-Australia.pdf

[31] J. Somlai, V.Jobbagy, J. Kovacs, S. Tarjan, T. Kovacs. (2008). Radiological aspects of the usability of red mud as building material additive. Journal of Hazardous Materials. 150, 541-545.

[32] H. Gu, N. Wang and S. Liu. (2012). Radiological restrictions of using red mud as building material additive. Waste Management \& Research 30(9), 961-965.

[33] V. Cuccia, A. H. de Oliveira and Z. Rocha. (2011). Radionuclides in Bayer process residues: previous analysis for radiological protection. 2011 International Nuclear Atlantic Conference - INAC 2011. ISBN: 978-85-99141-04-5. (7 pages).

[34] L. D. Hai, N. M. Khai, T. V. Quy and N. X. Huan (2014). Material composition and properties of red mud coming from alumina processing plant Tanrai, Lamdong, Vietnam. International Journal of Research In Earth \& Environmental Sciences. 1, 6. 7.

[35] Milačič R, Zuliani T, Ščančar J. (2012) Environmental impact of toxic elements in red mud studied by fractionation and speciation procedures. Sci Total Environ. 426, 359-365. doi: 10.1016/j.scitotenv.2012.03.080.
Radon Exhalation from Industrial Residues as Suitable Additives for Building Materials 